\title{
Traditions of early human groups in Baja California and possible routes for the peopling of the peninsula
}

\author{
Harumi Fujita ${ }^{1, *}$ and Amira F. Ainis ${ }^{2}$ \\ ${ }^{1}$ Centro INAH B.C.S., Legaspy 1637, Col. Los Olivos, La Paz, BCS, 23040, Mexico \\ ${ }_{2}$ Museum of Natural and Cultural History, Department of Anthropology, University of Oregon, Eugene, OR
}

\begin{abstract}
Ideas concerning the initial peopling of the Baja California Peninsula have dramatically changed in recent decades. In the late 19th and early 20th centuries, the native inhabitants of the southern part of the Baja California Peninsula were believed by some to have come from Melanesia, based on the perceived similarity in skull morphology. Since the middle of the 20th century, most researchers propose that initial populations entered from the north by land, bringing with them 2 distinct cultural traditions. The first wave was thought to have been an incursion of Paleoindians with Clovis-type fluted points. The second wave refers to groups who occupied ancient lake shores, such as Laguna Seca Chapala, and who were considered as belonging to the Western Pluvial Lakes (WPL) tradition. Eventually people moved down to the southern tip of the peninsula, pushed by subsequent groups. The entry of human groups from the Mexican mainland across the islands in the central Gulf of California has also been suggested; early entries by other groups have been proposed as well. A migration from Australia to the Cape Region across the southern Pacific has also been argued. This paper summarizes recent archaeological evidence from radiocarbon dates, geomorphological settings, subsistence strategies, and material types and technologies indicating that Paleocoastal migrants may have reached the Cape Region during the Terminal Pleistocene. However, some of the early lithic artifacts and technologies in the Cape Region show similarities to the WPL tradition, such as leaf-shaped points, an eccentric crescent, and end and side scrapers. This evidence suggests that perhaps a Paleocoastal group and a WPL group reached the southern part of the peninsula at around the same time and that they had some kind of interrelation that is reflected in their lifestyles and materials, which were principally adapted to coastal life.
\end{abstract}

Resumen.-Las opiniones acerca del población inicial en la península de Baja California cambiaron drásticamente en las últimas décadas. A fines del siglo XIX y principios del siglo XX, se creía que los habitantes nativos del sur de la península de Baja California provenían de Melanesia, basándose en la similitud percibida en la morfología craneal. Desde mediados del siglo XX, la mayoría de los investigadores proponen que las poblaciones iniciales ingresaron por tierra desde el norte, trayendo consigo dos tradiciones culturales distintas. Se pensó, que la primera ola inmigratoria se debió a la incursión de paleoindios con lanzas acanaladas de punta Clovis. La segunda ola se refiere a grupos que ocuparon las antiguas orillas de los lagos, como el de Laguna Seca Chapala, quienes fueron considerados como pertenecientes a la tradición de los lagos pluviales occidentales (WPL, por sus siglas en inglés). Eventualmente, la gente se trasladó al extremo sur de la península, impulsada por subsecuentes grupos. Asimismo, se sugirió el ingreso de grupos humanos por tierras mexicanas, a través de las islas del Golfo central de California, y la entrada de otros grupos en épocas más recientes. Finalmente, se argumentó la migración proveniente de Australia hacia la Región del Cabo en el Pacífico sur. Este artículo resume reciente evidencia arqueológica obtenida mediante datación por radiocarbono, las características geomorfológicas, las estrategias de subsistencia y tipos de materiales y tecnologías, indican que los migrantes paleo costeros pudieron llegar a la Región del Cabo a finales del Pleistoceno. Sin embargo, algunos de los primeros artefactos y tecnologías líticas en la Región del Cabo, tales como lanzas con forma de hoja, láminas en forma de media luna excéntricas y raspadores laterales, muestran similitudes con los de la tradición de WPL. Esta evidencia sugiere que probablemente un grupo Paleo costero y un grupo de los WPL llegaron al sur de la península casi al mismo tiempo y tuvieron alguna clase de interrelación, la cual se refleja en sus estilos de vida y materiales, que se adaptaron principalmente a la vida costera.

Several hypotheses have been presented concerning the nature of the initial human occupation of the Baja California Peninsula (Fig. 1). In the late 19th and early 20 th centuries, the native inhabitants of the southern part of the Baja California Peninsula were believed by some to have come from Melanesia, based on the perceived similarity in skull morphology (Rivet 1909) in the analyses conducted by ten Kate (1883) and Diguet (1905).

*Corresponding author: harumifuj@gmail.com 


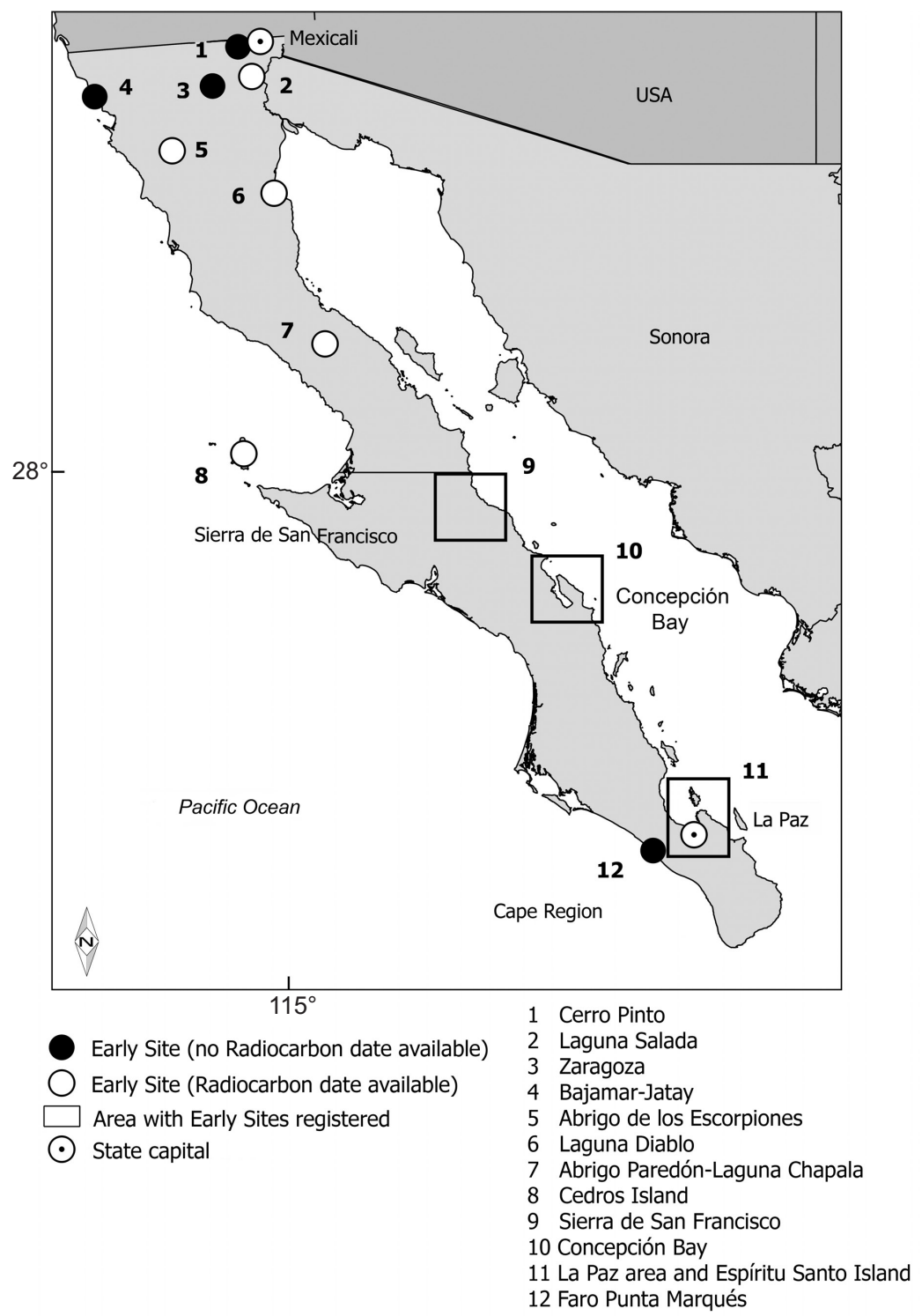

Fig. 1. Locations of Early Holocene sites and areas with a concentration of early sites on the Baja California Peninsula.

This hypothesis, however, did not consider factors such as mutation, material culture, and differences in environments and time periods.

In the middle of the 20th century, 2 prevalent scenarios emerged suggesting that the inhabitants followed a terrestrial route from the north. These hypotheses continue to be supported among researchers. The first hypothesis suggests the incursion of Paleoindians with Clovis-type fluted points (Aschmann 1952, Gutiérrez and Hyland 2002). Elsewhere in North America the Paleoindian and Clovis culture was a hunting tradition focused on Pleistocene megafauna such as mammoths, bison, and mastodons. The technology of Clovis-type fluted points and blades was followed by Folsom fluted points. The lithic elements in workshops of Paleoindian sites show evidence of reduction from formal conical cores and wedge-formed cores, as well as the reduction of bifaces.

The second scenario is the entry of hunting groups that occupied ancient lake shores (Arnold 1957). Later classified as the Western 


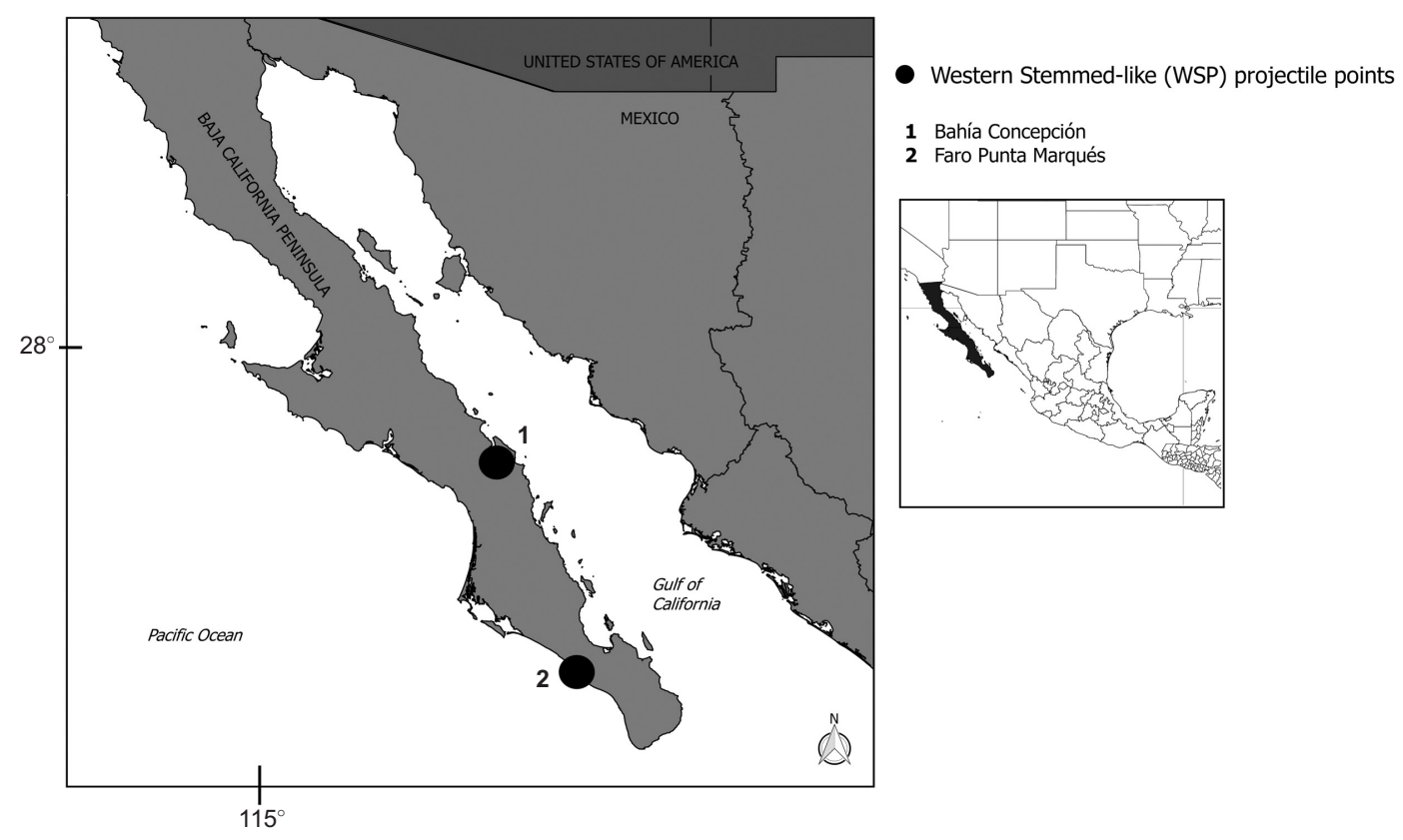

Fig. 2. Locations of Western Stemmed-like projectile points discovered in Baja California.

Pluvial Lakes (WPL) or Western Stemmed Point (WSP) tradition, they may have entered the peninsula before, contemporary with, or after the Clovis tradition. Typical WPL artifacts include stemmed points, leaf-shaped points, and end and side scrapers. The San Dieguito complex (Rogers 1966, Porcayo Michelini 2005) is considered a regional variant of the WPL tradition. The concept of the WPL tradition proposed by Bedwell (1973) refers to a lifestyle oriented and adapted to ancient lakes that covered many valleys and extensive lowlands throughout the Great Basin between 11,000 and 8000 years ago. A large number of stemmed points such as the Lake Mojave and Silver Lake types were found in these lowland areas, though not all sites of the WPL tradition contain stemmed points (Beck and Jones 1997, Davis et al. 2012). In Paisley Cave in Oregon, various obsidian stemmed points were found in Terminal Pleistocene deposits along with a human coprolite sample dated to $12,450 \pm 30 \mathrm{BP}$ (Jenkins et al. 2012). Several Western Stemmed points have been found on the peninsula of Baja California. Ritter (2006:103, 104) reports on the discovery of 2 Lake Mojave and Silver Lake-like points from Concepción Bay (Fig. 2). In addition, a projectile point similar to Silver
Lake types was found on the surface at a site along the southern Pacific coast of the peninsula at the Faro Punta Marqués site (Figs. 2, 3; Fujita and Hernández Velázquez 2017). This projectile point is elongated and slender, and lateral morphology displays differences on both sides. One side has a very weak shoulder and the other exhibits a weak side notch indentation. The dimensions of this point are $4.55 \mathrm{~cm}$ long, $1.85 \mathrm{~cm}$ wide, and $0.9 \mathrm{~cm}$ thick. The raw material is rhyolite, which has a much coarser grain than chert and obsidian. The points found in Baja California display some similarity in form but significant differences in raw material and technology, so they cannot be clearly classified as Western Stemmed points; instead, they can be classified as Western Stemmed-like points. Some researchers have suggested that the initial groups were pushed south to the tip of the peninsula as other groups moved in from the north (Rogers 1945, Massey 1966, Kowta 1984). However, it seems that local social and cultural developments in response to local requirements and climatic fluctuations also played an important role.

The entry of human groups from the Mexican mainland across the islands (such as Tiburón, San Esteban, San Lorenzo, and 


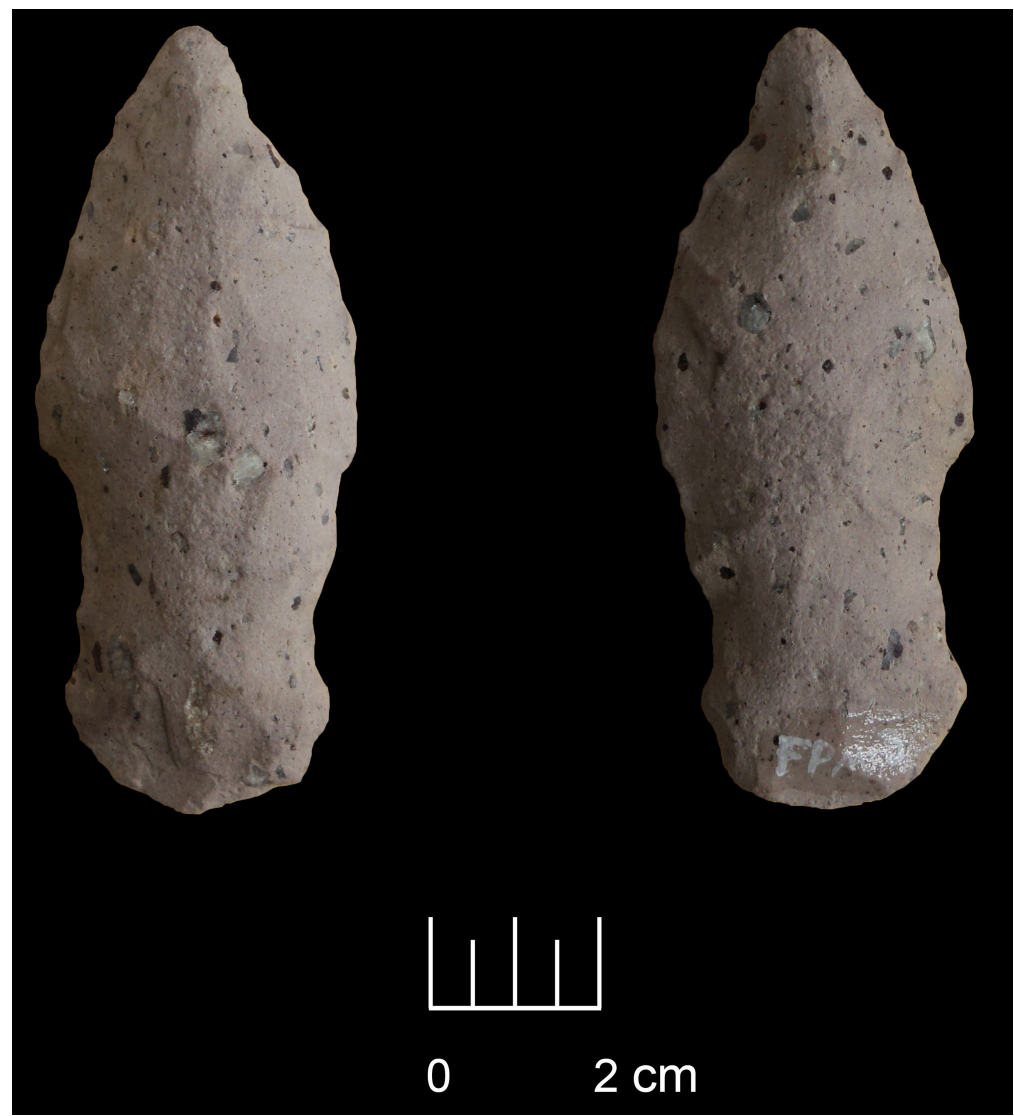

Fig. 3. A Silver Lake-like point from the Faro Punta Marqués site on the southern Pacific coast of Baja California.

Ángel de la Guarda Islands) in the central Gulf of California has also been suggested, and early entries by other groups have been proposed as well (Kowta 1984). However, no diagnostic materials from the Terminal Pleistocene/Early Holocene have been uncovered on any of these islands or in the surrounding areas (Bowen 2009). Although it has been pointed out that much of the archaeology of Baja California is unknown, archaeological investigations increased in some regions of the peninsula after the beginning of the 21st century, especially in the north, in the central region including Sierra de San Francisco and Sierra de Guadalupe, on Cedros Island, and in the Cape Region (Laylander and Moore 2006).

Recent archaeological evidence suggests additional early entries by other human groups. Radiocarbon dates, geomorphological settings, subsistence strategies, material types, and technologies indicate that Paleocoastal migrants may have reached the Cape Region by the Terminal Pleistocene (Fujita 2010, 2014, Fujita and Melgar 2014, Fujita and Porcayo Michelini 2014, Fujita et al. 2017). Select artifacts from Terminal Pleistocene and Early Holocene contexts in the Cape Region are similar to those identified for the WPL tradition and Paleocoastal sites in California and the Great Basin (Table 1). Similar lithic artifact types include leaf-shaped projectile points, an eccentric crescent, and end and side scrapers. However, there are some differences. In the Cape Region sites, the use of shells and coral for tools, containers, and ornaments was prominent, as were milling tools (Fig. 4). At the Covacha Babisuri site on Espíritu Santo Island (Fig. 5), some unique items were uncovered in the lowest cultural stratum (ca. 12,000-8000 BP). Fossil shells, both modified and unmodified, dated between 35,500 and $>47,500$ years ago, were used 
Table 1. Cultural elements in Paleocoastal sites/areas and Western Stemmed Point tradition sites (including San Dieguito sites) $)^{\mathrm{a}}$. $\mathrm{X}=$ presence.

\begin{tabular}{|c|c|c|c|c|c|c|c|c|c|c|c|c|c|}
\hline \multirow[b]{2}{*}{ Cultural elements } & \multicolumn{8}{|c|}{ Paleocoastal Tradition } & \multicolumn{5}{|c|}{ Western Pluvial Lakes Tradition } \\
\hline & $\mathrm{ChI}^{\mathrm{b}}$ & $\mathrm{RPN}$ & DC & $\mathrm{IC}$ & $\mathrm{AE}$ & $\mathrm{CB}$ & $\mathrm{CC}$ & CT & $\mathrm{LCh}$ & AP & $\mathrm{CP}$ & $\mathrm{IZ}$ & $\mathrm{PC}$ \\
\hline Stemmed points & $\mathrm{X}$ & & $\mathrm{X}$ & $\mathrm{X}$ & & $\mathrm{X}$ & & & & & & & $\mathrm{X}$ \\
\hline Barbed stemmed points & $\mathrm{X}$ & & & & & & & & & & & & \\
\hline Leaf-shaped points or knives & $\mathrm{X}$ & $\mathrm{X}$ & $\mathrm{X}$ & $\mathrm{X}$ & $\mathrm{X}$ & $\mathrm{X}$ & & & & $\mathrm{X}$ & $\mathrm{X}$ & $\mathrm{X}$ & \\
\hline Elongated bifacial knives & & $\mathrm{X}$ & & & & & & & & & & $\mathrm{X}$ & \\
\hline Large elongated bifaces & & & & & & & & & $\mathrm{X}$ & & & & \\
\hline Crescents & $\mathrm{X}$ & $\mathrm{X}$ & & & & $\mathrm{X}$ & & & & & & $\mathrm{X}$ & \\
\hline Milling stones & & & $\mathrm{X}$ & $\mathrm{X}$ & $\mathrm{X}$ & $\mathrm{X}$ & $\mathrm{X}$ & & & & & & \\
\hline Pitted stones & & & $\mathrm{X}$ & & & $\mathrm{X}$ & $\mathrm{X}$ & & & & & & \\
\hline Scrapers & & $\mathrm{X}$ & $\mathrm{X}$ & $\mathrm{X}$ & $\mathrm{X}$ & $\mathrm{X}$ & $\mathrm{X}$ & $\mathrm{X}$ & $\mathrm{X}$ & & $\mathrm{X}$ & $\mathrm{X}$ & \\
\hline Blades & & $\mathrm{X}$ & $\mathrm{X}$ & & & $\mathrm{X}$ & $\mathrm{X}$ & & & & & & \\
\hline Drills & & & & & & $\mathrm{X}$ & $\mathrm{X}$ & & & & & $\mathrm{X}$ & \\
\hline Bone gorges & $\mathrm{X}$ & & & & & & & & & & & & \\
\hline Shell fishhooks & & & & $\mathrm{X}$ & & $\mathrm{X}$ & & & & & & & \\
\hline Olivella spire-lopped beads & $\mathrm{X}$ & & $\mathrm{X}$ & & $\mathrm{X}$ & $\mathrm{X}$ & & $\mathrm{X}$ & & & & & \\
\hline $\begin{array}{l}\text { Shell tools } \\
\text { (scrapers, knives, punches } \\
\text { or drills) }\end{array}$ & & & & $\mathrm{X}$ & & $\mathrm{X}$ & $\mathrm{X}$ & $\mathrm{X}$ & & & & & \\
\hline Shell containers & & & & & & $\mathrm{X}$ & $\mathrm{X}$ & $\mathrm{X}$ & & & & & \\
\hline $\begin{array}{l}\text { Fossil shell tools and } \\
\text { containers }\end{array}$ & & & & & & $\mathrm{X}$ & $\mathrm{X}$ & $\mathrm{X}$ & & & & & \\
\hline Fluted pearls & & & & & & $\mathrm{X}$ & & & & & & & \\
\hline Coral reamers & & & & & & $\mathrm{X}$ & & $\mathrm{X}$ & & & & & \\
\hline Worm shell tubes (pipes or & & & & & & $\mathrm{X}$ & & & & & & & \\
\hline straws?) & & & & & & & & & & & & & \\
\hline Bone tools & $\mathrm{X}$ & & $\mathrm{X}$ & & & $\mathrm{X}$ & & & & & & & \\
\hline Use of red ochre & $\mathrm{X}$ & & & & & $\mathrm{X}$ & & & & & & & \\
\hline
\end{tabular}

aData were compiled from the following sources: Moratto 1984, Porcayo Michelini 2005, Gruhn and Bryan 2008, Fujita 2008, 2010, 2014, Des Lauriers 2010, Jenkins et al. 2012, Fujita et al. 2013, Fujita and Melgar 2014, Fujita and Muñoz 2014b, Fujita and Porcayo Michelini 2014, and García Hernández et al. 2015.

${ }^{\mathrm{b}} \mathrm{ChI}=$ Northern Channel Islands, RPN $=$ Rancho Park North, DC = Diablo Canyon, $\mathrm{IC}=$ Isla de Cedros, $\mathrm{AE}=\mathrm{Abrigo}$ de los Escorpiones, $\mathrm{CB}=\mathrm{Covacha}$ Babisuri, CC = Cerro de la Calavera \# 1, CT = Cueva Tecolote \#2, LCh = Laguna Chapala, AP = Abrigo Paredón, CP = Cerro Pinto, IZ = Ignacio Zaragoza, PC $=$ Paisley Cave.

for containers and tools, especially scrapers (Fujita and Melgar 2014). Fluted pearl oyster (Pinctada mazatlanica) and clam (Megapitaria sp.) pearls were used to manufacture ornaments (Fig. 6b; Fujita et al. 2017). Pearl oysters were used to make fish hooks (Fig. 6c) and purple olive shells (Callianax spp.) were used to make spire-lopped beads (Fig. 6a). Fragments of coral were used as abraders (Fig. 6d) and worm snails (Vermetidae) served as straws or pipes (Fig. 6e, f; Fujita 2010, 2014, Fujita and Melgar 2014, Fujita et al. 2017). Most of these tools and ornaments continued to be manufactured and utilized during the Middle Holocene, except the fossil shells. Fishing, shellfish gathering, and sea turtle hunting were the principal subsistence activities, complemented by plant gathering. These characteristics are also considered part of the Paleocoastal tradition.

The hypothesis of the Paleocoastal tradition suggests that the first people to enter the Baja California Peninsula arrived from the Canadian and U.S. Pacific coast (Fladmark 1979, Rick et al. 2001, Erlandson et al. 2007). This theory received more support when eminent American archaeologists accepted the antiquity of the first occupation of 12,500 BP at the Monte Verde site in Chile, which is older than Clovis sites that are considered to be between 11,050 to 10,800 calendar years ago (Dillehey 1997, Meltzer et al. 1997, Fledge and Christensen 1999, Walters and Stafford 2007). There are human occupation sites of Terminal Pleistocene and Early Holocene age on the western coast of Canada and the United States, notably on California's Channel Islands, with evidence of the exploitation of marine resources (Carlson 1990, 1996, Ackerman 1992, Dixon 1993, 1999, Erlandson 1994, Erlandson and Moss 1996, Rick et al. 2001, 2013, Raab et al. 2009, Erlandson et al. 2011). Due to subsequent sea level rise, it is probable that the majority of the early sites located on or near the coast have been submerged. The early inhabitants collected shellfish, fished for a variety of 


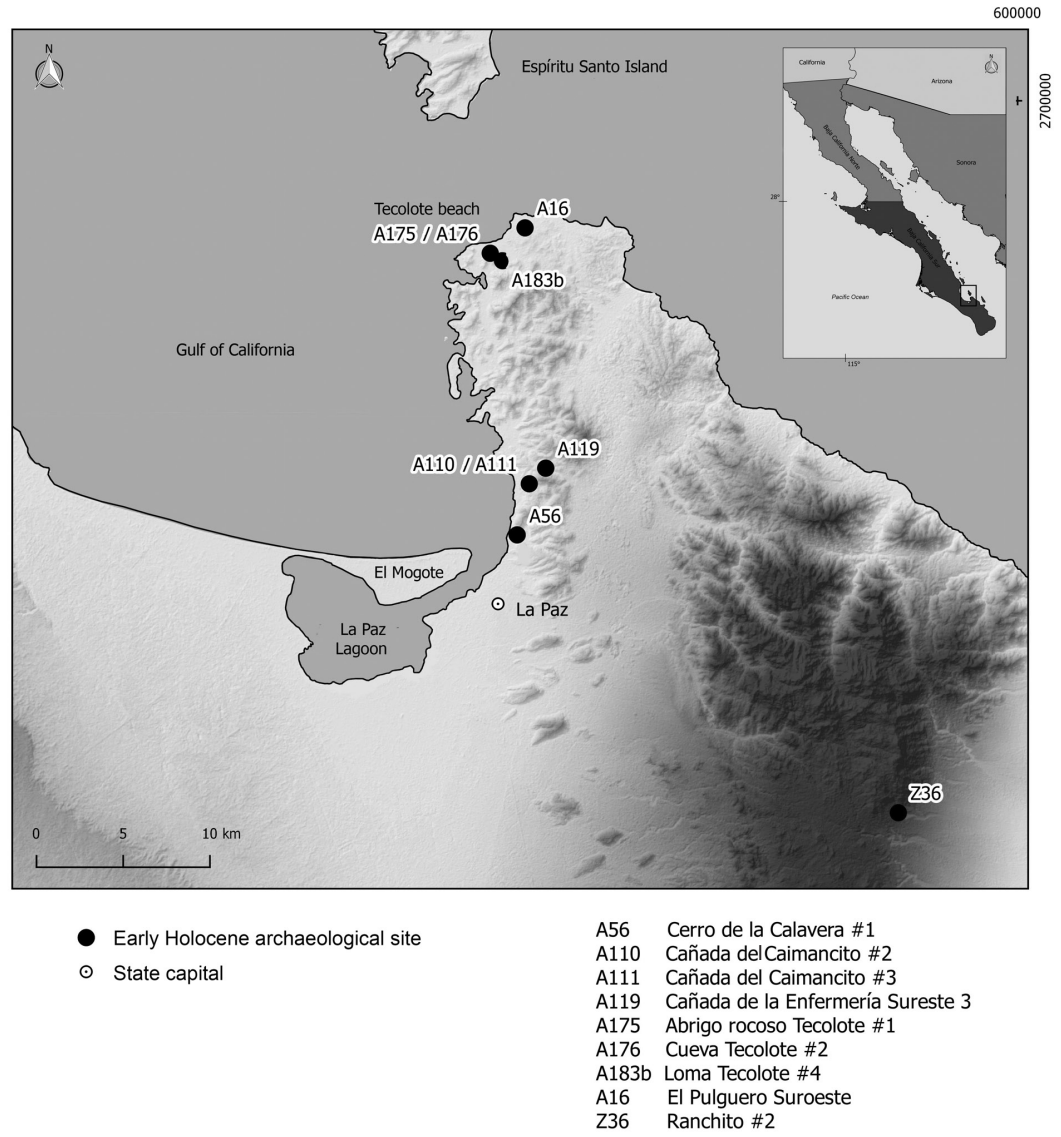

Fig. 4. Locations of Early Holocene sites in the La Paz area, Baja California Sur.

species, and captured a variety of marine mammals in addition to using terrestrial resources, principally plants in some regions. The dependence on terrestrial animal hunting appears to have been relatively low in coastal areas.

Beck and Jones (2010) suggested that the makers of chipped stone crescents and Western Stemmed points typical of the WPL tradition may have descended from coastal peoples who migrated from northeast Asia into the Americas. As they explored Pacific shorelines, some of these Paleocoastal people may have spread eastward, following major rivers to the lakes and marshes of the Great Basin and the Intermountain West. Erlandson et al. (2011) suggested that Paleocoastal stemmed points and crescents from the Channel Islands may provide a technological link between the Terminal Pleistocene stemmed point traditions of northeast Asia, the Pacific Northwest, and
South America. A migration from Australia to the Cape Region across the southern Pacific has also been argued based on craniometric studies (González-José et al. 2003). However, investigators have more recently proposed that the Cape Region inhabitants shared common ancestry with other native North Americans but had diverged as a result of isolation and the operation of random genetic factors (Laylander and Moore 2006:7).

\section{Terminal Pleistocene and Early Holocene Sites in Baja California}

In 1952 Homer Aschmann (1952) reported a Clovis point found on the surface at the ranch of San Joaquín located in the Sierra de San Francisco area in the central part of the peninsula (Fig. 1). In the same period, lithic tools including large bifaces and scrapers were observed on the edge of ancient Laguna Seca 


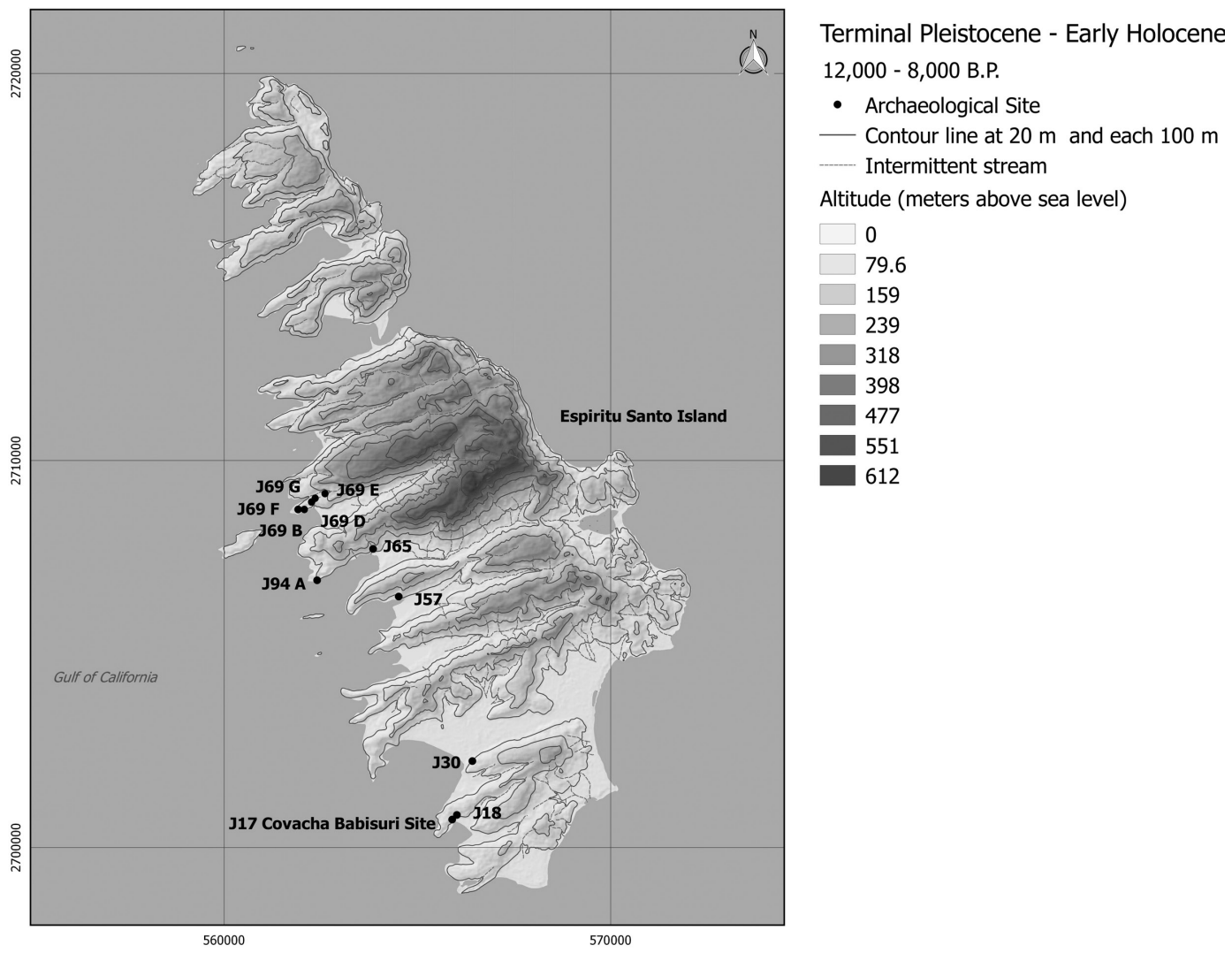

Fig. 5. Locations of 11 Terminal Pleistocene and Early Holocene sites dated to between 12,000 BP and 8000 BP on Espíritu Santo Island.

Chapala (Fig. 1), and Brigham Arnold (1957) and William Massey $(1955,1966)$ suggested that these sites might correspond to the Terminal Pleistocene and Early Holocene time periods. However, because these discoveries were made prior to the widespread use of radiocarbon dating, their antiquity was not proven.

Almost half a century later, additional archaeological discoveries of evidence of early human groups in Baja California were reported (Table 2). These include 2 more Clovis points in the Sierra de San Francisco region in the central part of the peninsula (Fig. 1) and a charcoal sample from excavations in the Cueva Pintada site that was dated to $10,860 \pm 90 \mathrm{BP}(12,983-12,643$ calBP $)$ (Gutiérrez and Hyland 2002).

A charcoal sample from the Abrigo de los Escorpiones rock shelter on the west coast of northern Baja California was dated to $8870 \pm$ 60 BP (10,184-9738 calBP). Chipped stones, milling stones, and hammer stones as well as shell and vertebrate faunal remains-principally sea lion with some fish, bird, sea otter, whale, and artiodactyl remains-were found in the Early Holocene deposits (Gruhn and Bryan 2008).

A charcoal sample from the Abrigo Paredón site near Laguna Seca Chapala has been dated to $9070 \pm 60 \mathrm{BP}(10,414-10,151$ calBP $)$ (Gruhn and Bryan 2008). This site appears to have been used as a workshop to reduce large felsite biface preforms to smaller and thinner bifaces and leaf-shaped points and knives (Gruhn and Bryan 2008:6).

On Cedros Island in the Pacific Ocean, 2 sites were excavated and various charcoal and shell samples were dated to earlier than 10,000 BP. The oldest charcoal date was $10,380 \pm 60 \mathrm{BP}(12,520-12,476$ calBP $)$ and the oldest shell date was $10,745 \pm 25 \mathrm{BP}$ (12,323-11,892 calBP) (Des Lauriers 2010). Projectile points, knives, and scrapers as well as shell tools associated with fish, sea turtle, 

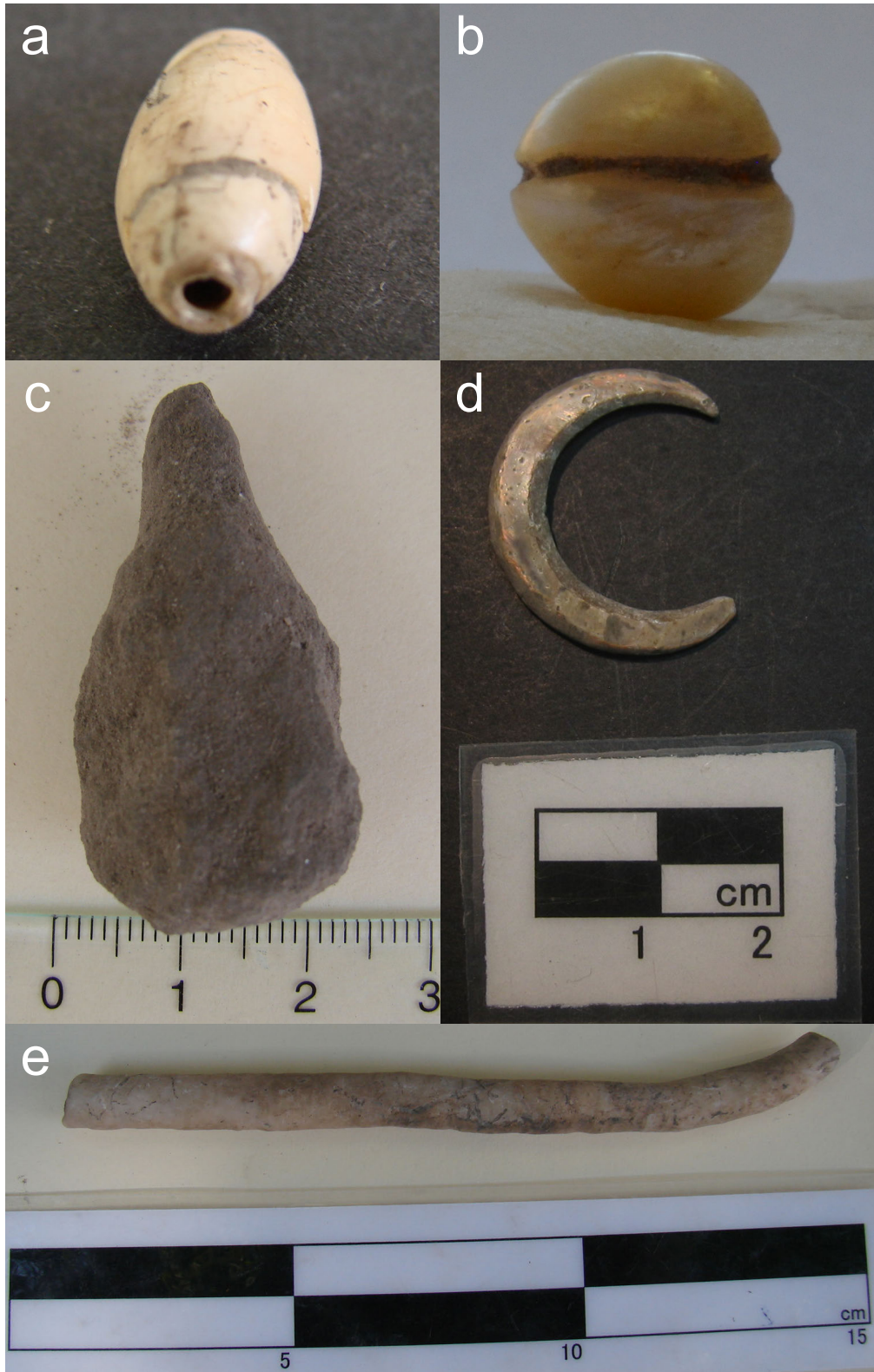

f

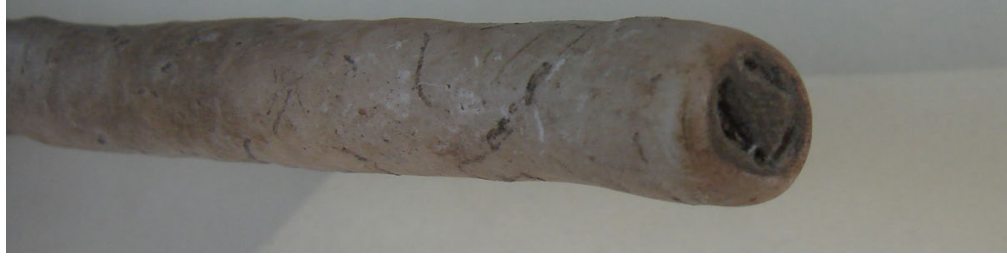

Fig. 6. Shell ornaments and tools from the Covacha Babisuri site: a, Olivella spire-lopped bead; b, Pinctada mazatlanica fluted pearl; c, pearl oyster fishhook preform; d, coral abrader; e, pipe or straw of worm shell (Vermetidae) with one end abraded; $\mathbf{f}$, detail of the polished end of the worm shell straw with a fragment of shell attached at its end. 
Fujita and Ainis • Traditions of Early Humans in Baja California

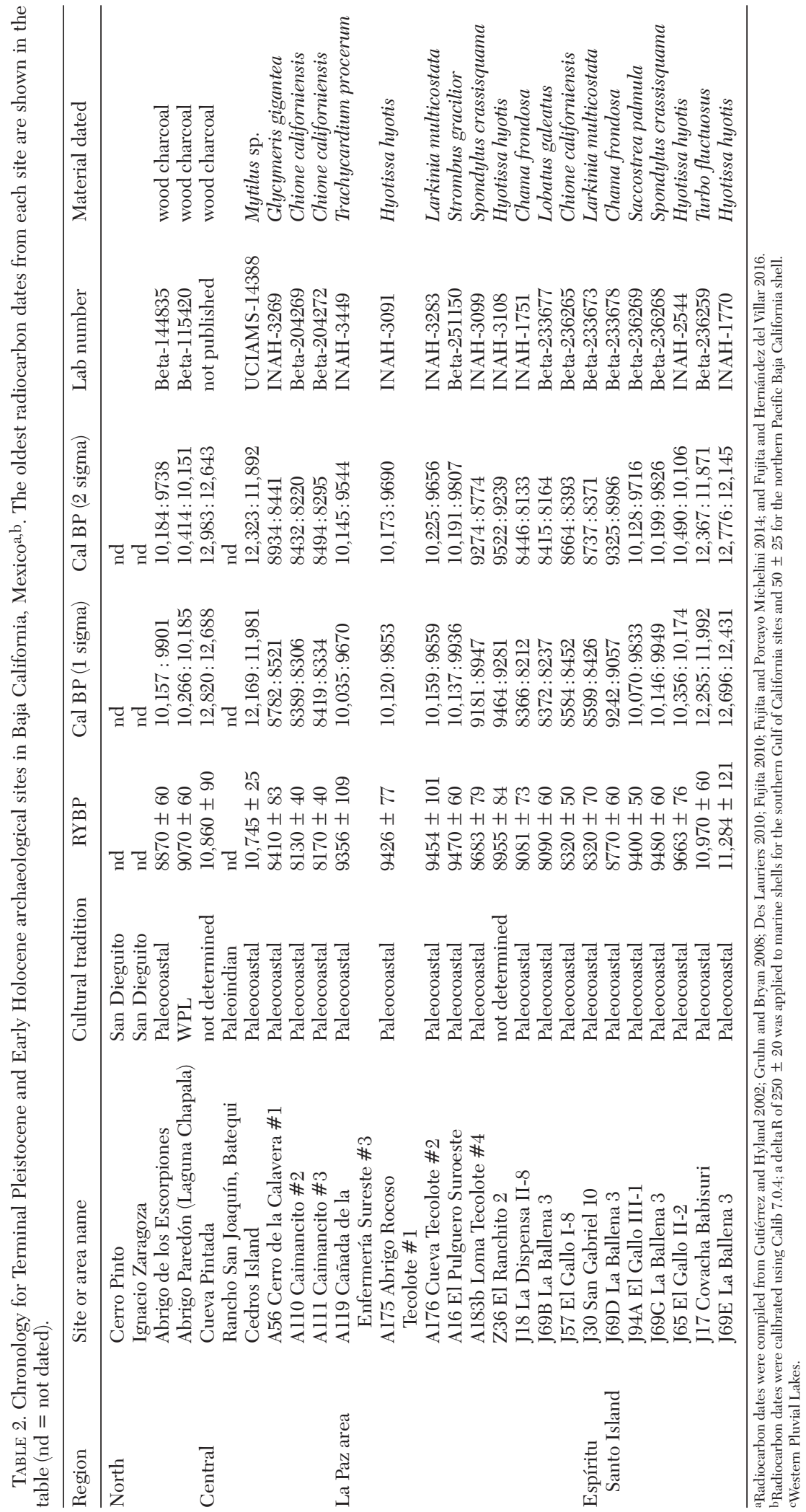




\section{Faunal remains in Early Holocene deposits at the \\ Covacha Babisuri site}

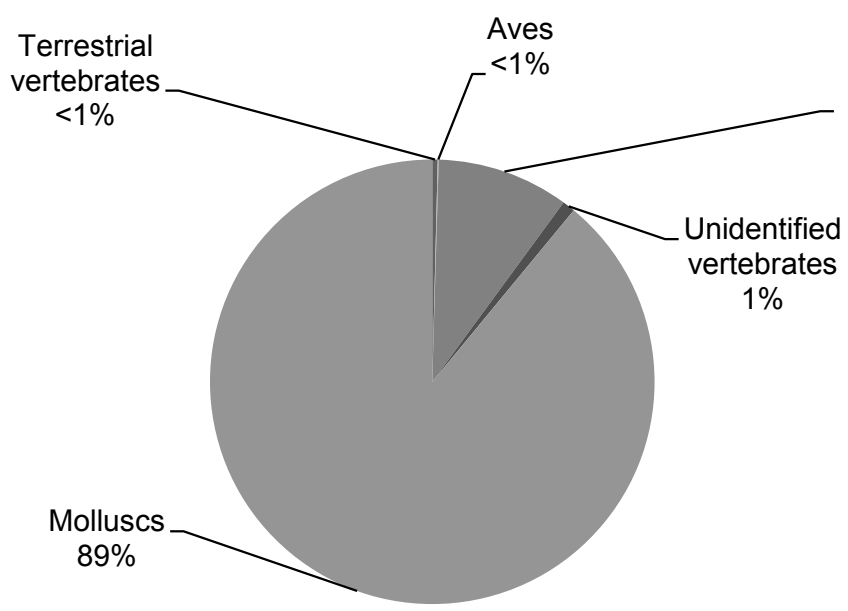

Teleosts, cetaceans, and marine reptiles and mammals $10 \%$

Fig. 7. Composition of faunal remains in Early Holocene deposits at the Covacha Babisuri site. Note: "marine reptiles" refers to marine turtles.

TABLE 3. Composition of vertebrate remains from Early Holocene deposits at the Covacha Babisuri site.

\begin{tabular}{lllr}
\hline Marine or terrestrial & Taxon & Common name & NISPa \\
\hline Terrestrial vertebrates & Ophidia & snakes & 4 \\
& Leporidae & rabbits and hares & 10 \\
& Sylvilagus & rabbits & 3 \\
& Rodentia & mice and rats & 23 \\
& Odocoileus & deer & 2 \\
Marine or terrestrial birds & Aves & birds & 33 \\
& Teleost and elasmobranch & fish, sharks, and rays & 4309 \\
Marine vertebrates & Chelonia & sea turtles & 128 \\
& Pinnipedia & sea lions and seals & 2 \\
Unidentified vertebrates & Zalophus & sea lions and seals & 6 \\
& Cetacea & whales, dolphins, and porpoises & 4 \\
& unidentified vertebrates & & 568 \\
\hline
\end{tabular}

aNumber of individual specimens

and sea otter remains were recovered from the Terminal Pleistocene/Early Holocene deposits at these sites (Des Lauriers 2010).

In the Cape Region there are 20 sites that correspond to the Terminal Pleistocene and Early Holocene: 11 sites on Espíritu Santo Island including Covacha Babisuri (Fig. 5), 8 sites in the area between La Paz and TecoloteEl Pulguero, and one site on the eastern slope of the Sierra de las Cacachilas (Fig. 4; Fujita and Poyatos 2007, Fujita 2010, Fujita and Melgar 2014, Fujita and Bulhusen Muñoz 2014a, 2014b). The Covacha Babisuri site contains the earliest excavated sample of archaeological materials. In the lowest stratum, a marine shell was dated to $10,970 \pm 60 \mathrm{BP}$
$(12,367-11,871$ cal BP); more than 100 radiocarbon samples from this site establish the antiquity of various occupational periods.

Shellfish remains are abundant in these early sites, implying a significant focus on marine resources. Marine faunal remains at the Covacha Babisuri site account for more than $99 \%$ of all faunal specimens in the Early Holocene deposits, with shellfish constituting $\sim 89 \%$. Remains of terrestrial fauna are present in extremely low numbers, accounting for $<1 \%$ of the faunal assemblages (Fig. 7, Table 3). Among the shellfish remains, mangrove oyster (Saccostrea palmula) was the most often consumed, followed by Turbo fluctuosus, Strombus gracilior, pearl oyster (Pinctada 
TABLE 4. Frequency of shellfish taxa uncovered in the Early Holocene levels of the Covacha Babisuri site, Espíritu Santo Island, Baja California Sur.

\begin{tabular}{|c|c|c|c|}
\hline Bivalve taxon & Number of valves & Gastropod taxon & $\begin{array}{l}\text { Minimum number } \\
\text { of individuals }\end{array}$ \\
\hline Saccostrea palmula & 33635 & Turbo fluctuosus & 4444 \\
\hline Pinctada mazatlanica & 7703 & Strombus gracilior & 3953 \\
\hline Carditamera affinis & 1467 & Nerita scabricosta & 2209 \\
\hline Chione californiensis & 2035 & Persististrombus granulatus & 1994 \\
\hline Chione undatella & 976 & Lobatus galeatus & 512 \\
\hline Codakia distinguenda & 788 & Stramonita biserialis & 349 \\
\hline Dosinia ponderosa & 1440 & Cerithium maculosum & 241 \\
\hline Myrakeena angelica & 51 & Crucibulum spp. & 164 \\
\hline Lyropecten subnodosus & 849 & Trypsycha sp. & 39 \\
\hline Callista squalida & 615 & Neorapana tuberculata & 70 \\
\hline Glycymeris gigantea & 888 & Fusinus dupetitthouarsi & 64 \\
\hline Hyotissa hyotis & 359 & Hexaplex erythrostomus & 59 \\
\hline Pinna rugosa & 201 & Neverita aulacoglossa & 48 \\
\hline Glycymeris maculata & 215 & Callianax sp. & 63 \\
\hline Laevicardium elatum & 582 & Collisella sp. & 20 \\
\hline Chama frondosa & 94 & Pseudozonaria annettae & 51 \\
\hline Modiolus capax & 212 & Conus sp. & 44 \\
\hline Spondylus crassisquama & 224 & Vasula speciosa & 30 \\
\hline Chama mexicana & 39 & Malea ringens & 37 \\
\hline Callista aurantiaca & 129 & Macrocypraea cervinetta & 37 \\
\hline Larkinia multicostata & 99 & Oliva sp. & 43 \\
\hline Pseudochama sp. & 41 & Crepidula sp. & 31 \\
\hline Arca pacifica & 71 & Conus princeps & 17 \\
\hline Euvora vogdesi & 90 & Uvanilla sp. & 49 \\
\hline Isognomon janus & 41 & Vasum caestus & 17 \\
\hline Tucetona multicostata & 19 & Tribulus planospira & 11 \\
\hline Spondylus limbatus & 23 & Neverita recluziana & 2 \\
\hline Trachycardium consors & 19 & Hexaplex nigritus & 19 \\
\hline Periglypta multicostata & 37 & Thaisella kiosquiformis & 11 \\
\hline Barbatia reeveana & 36 & Oliva porphyria & 6 \\
\hline Trachycardium procerum & 22 & Triplofusus princeps & 7 \\
\hline Glycymeris g. or Dosinia p. ${ }^{\mathrm{a}}$ & 33 & Pomaulax spiratus & 8 \\
\hline Argopecten ventricosus & 12 & Turritella sp. & 5 \\
\hline Tivela sp. & 3 & Pseodozonaria sp. & 6 \\
\hline Chione tumens & 8 & Arquitectonica nobilis & 1 \\
\hline Leukoma grata & 5 & Neorapana muricata & 5 \\
\hline Trigoniocardia biangulata & 2 & Cymia tectum & 2 \\
\hline Larkinia grandis & 1 & Favartia lappa & 2 \\
\hline Chione sp. & 1 & Mitridae & 1 \\
\hline Spondylus sp. & 2 & unidentified & 29 \\
\hline Anadara tuberculosa & 1 & TOTAL & 14,700 \\
\hline Chama buddiana & 1 & 1U1AL & 14,100 \\
\hline Pitar berryi & 1 & & \\
\hline unidentified & 63 & & \\
\hline TOTAL & 53,133 & & \\
\hline
\end{tabular}

${ }^{\mathrm{a} G l y c y m e r i s ~ g i g a n t e a}$ or Dosinia ponderosa

mazatlanica), Nerita scabricostata, Persististrombus granulatus, and other bivalves and gastropods (Table 4, Fig. 8). Fish and urchin remains are also present at most of the sites but in much lower densities. At the Covacha Babisuri site, 18 fish and elasmobranch families and one fish order were identified in the Early Holocene deposits, among which Balistidae (trigger fish), Scombridae (tuna), Serranidae (grouper), Carangidae (mackerel),
Diodontidae (porcupine fish), Scaridae (parrot fish), and Lutjanidae (red snapper) were the most common (Fig. 9; Guía 2008, 2011). Although the frequency of tuna remains is high, we do not believe that this necessarily suggests the use of boats for pelagic fishing because juveniles especially are known to be caught close to shore. Sea turtle, sea lion, chiton, crab, deer, hare, and rabbit remains were also recovered in some of these sites. Shell 


\section{Molluscan remains in Early Holocene deposits at the Covacha Babisuri site}

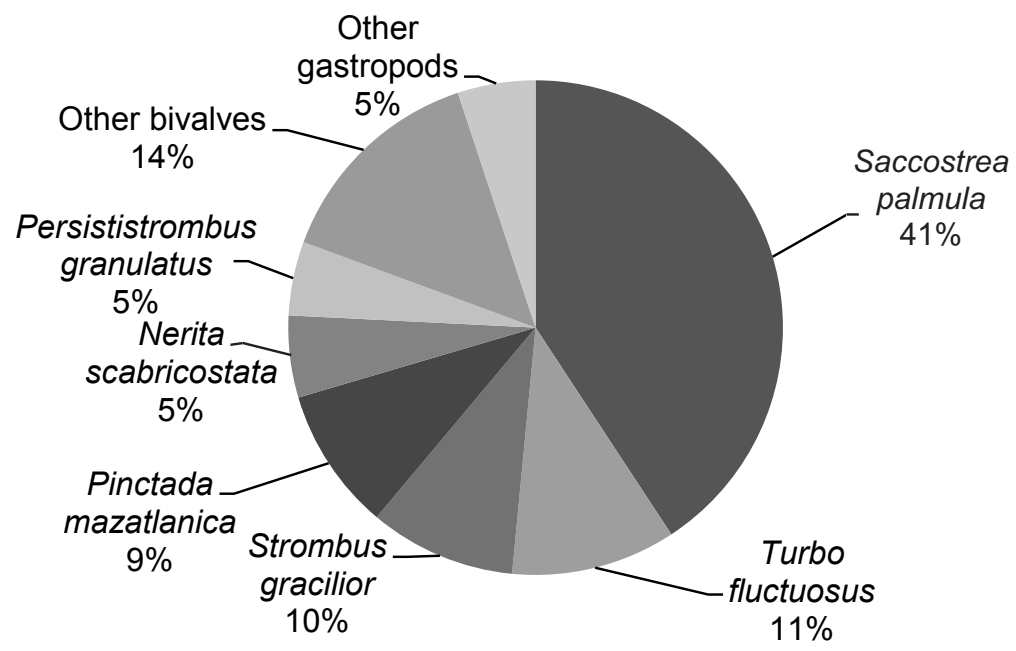

Fig. 8. Composition of shellfish remains in Early Holocene deposits at the Covacha Babisuri site.

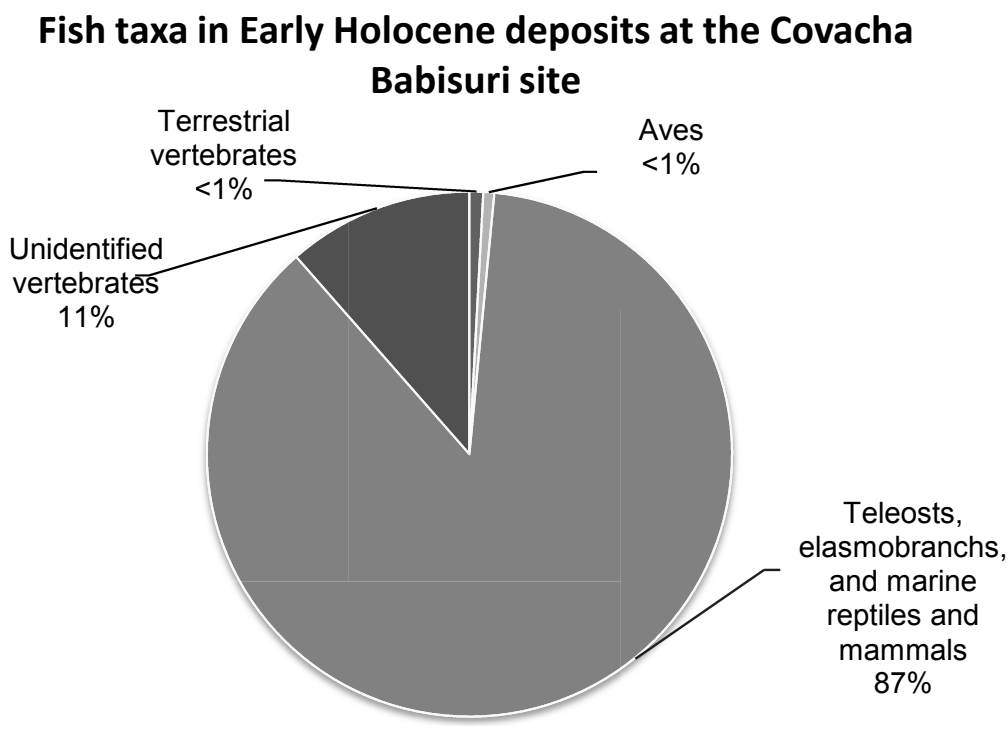

Fig. 9. Fish taxa identified in Early Holocene deposits at the Covacha Babisuri site.

and coral tools, containers, and ornaments in addition to diverse types of lithics were the principal artifacts; similar shell artifacts were also found in early sites on Cedros Island but not on the Channel Islands to the north (Des Lauriers 2010). In addition, one bone awl was also uncovered in the early deposits at the Covacha Babisuri site.
The sites of Ignacio Zaragoza and Cerro Pinto in northern Baja California are considered Early Holocene sites exhibiting the San Dieguito cultural tradition based on the similarity of their lithic assemblages to those of San Dieguito sites in other regions, although there have been no radiocarbon analyses. Lithics from these sites include leaf-shaped 
projectile points, eccentric crescents, knives, scrapers, drills, burins, hammer stones, and choppers (Porcayo Michelini 2005, 2009; Fujita and Porcayo Michelini 2014).

\section{Terrestrial Migration Routes}

The presence of these early sites suggests 2 different scenarios: The first is that early inhabitants arrived by land and the second is that they followed a coastal route along the Pacific. The terrestrial scenario has 2 variants, known as the Paleoindian incursion and the Western Pluvial Lakes (WPL) or Western Stemmed Point (WSP) tradition, including the local variant known as the San Dieguito complex (Fig. 10; Moratto 1984, Bryan 1988, Beck and Jones 1997).

In Baja California, Clovis points have been found in the Sierra de San Francisco area (Aschmann 1952, Hyland and Gutiérrez 1995), on Cedros Island (Des Lauriers 2010), and near Ciudad Constitución (C. Mandujano, personal communication, 2013); no Clovis points have been reported in the northern or southern parts of the peninsula. In addition, no lithic workshops for this type of point have been identified on the peninsula. As for Western Stemmed points, Ritter (2006) reported the presence of projectile points similar to Lake Mojave and Silver Lake types on the surface near Concepción Bay in the south central part of the peninsula (Fig. 2). The characteristics of the tools and the geomorphological nature of the Laguna Seca Chapala, Ignacio Zaragoza, and Cerro Pinto sites suggest associations with the WPL tradition (Porcayo Michelini 2005, 2009, Fujita and Porcayo Michelini 2014). A projectile point similar to Silver Lake types was found on the surface at a site along the southern Pacific coast of the peninsula at a site designated as Faro Punta Marqués (Figs. 2, 3; Fujita and Hernández Velázquez 2017).

\section{Coastal Migration Route}

The early sites on Cedros Island, the sites located between La Paz and Tecolote, and the sites on Espíritu Santo Island have characteristics distinct from both terrestrial traditions with respect to some of the archaeological materials and faunal remains. At these sites diverse species of fish, sea lions, marine turtles, shellfish, crustaceans, and sea urchins were exploited and specific artifacts such as shell tools (fish hooks, scrapers, drills,), shell containers and ornaments, coral abraders, and worm pipes were used (Fig. 6a-f). At the Covacha Babisuri site on Espíritu Santo Island, cetacean, deer, and hare remains were also recovered (Table 3).

The human groups of the Late Pleistocene and Early Holocene with strong orientations toward marine resources are considered Paleocoastal people (Davis et al. 1969, Moratto 1984, Erlandson et al. 2007, 2008, 2011, Erlandson 2012, Jones and Kennett 2012). Some researchers consider this tradition to be a variant of the WPL tradition (Davis et al. 1969). Alternatively, the WPL tradition may have descended from coastal peoples who migrated from northeast Asia to the Americas, and some of these Paleocoastal people may have spread eastward, following major rivers to the lakes and marshes of the Great Basin and the Intermountain West (Beck and Jones 2010, Erlandson and Braje 2011, Erlandson 2012). In spite of the presence of lithic artifacts common to both traditions, there are other artifacts exclusive to the Paleocoastal tradition, such as tools made of shells and coral, including ornaments, containers, and fish hooks (Table 1). Subsistence remains reveal a very strong orientation to the exploitation of marine resources, complemented by plant gathering and terrestrial animal hunting to a minor extent.

It is likely that the majority of early coastal sites were submerged by the rise in sea level at the end of the Pleistocene, submerging the record of the earliest sites between Cedros Island and Espíritu Santo Island. On both islands technology was developed for fishing and capturing sea turtles and other marine vertebrates (i.e., shell fish hooks and lance points). Fish hooks were manufactured with pearl oysters (Pinctada mazatlanica; Fig. 6c) on Espíritu Santo Island and mussel shells (Mytilus) on Cedros Island (Des Lauriers 2010, Fujita 2010, 2014, Fujita and Melgar 2014).

As for tools, Clovis and leaf-shaped projectile points, knives, end scrapers, and side scrapers as well as shell tools were recovered on Cedros Island (Table 1; Des Lauriers 2010). A variety of artifacts composed of end and side scrapers, unimarginal knives, projectile points, a fragment of an eccentric crescent, blades and flakes with and without retouch, and cores 


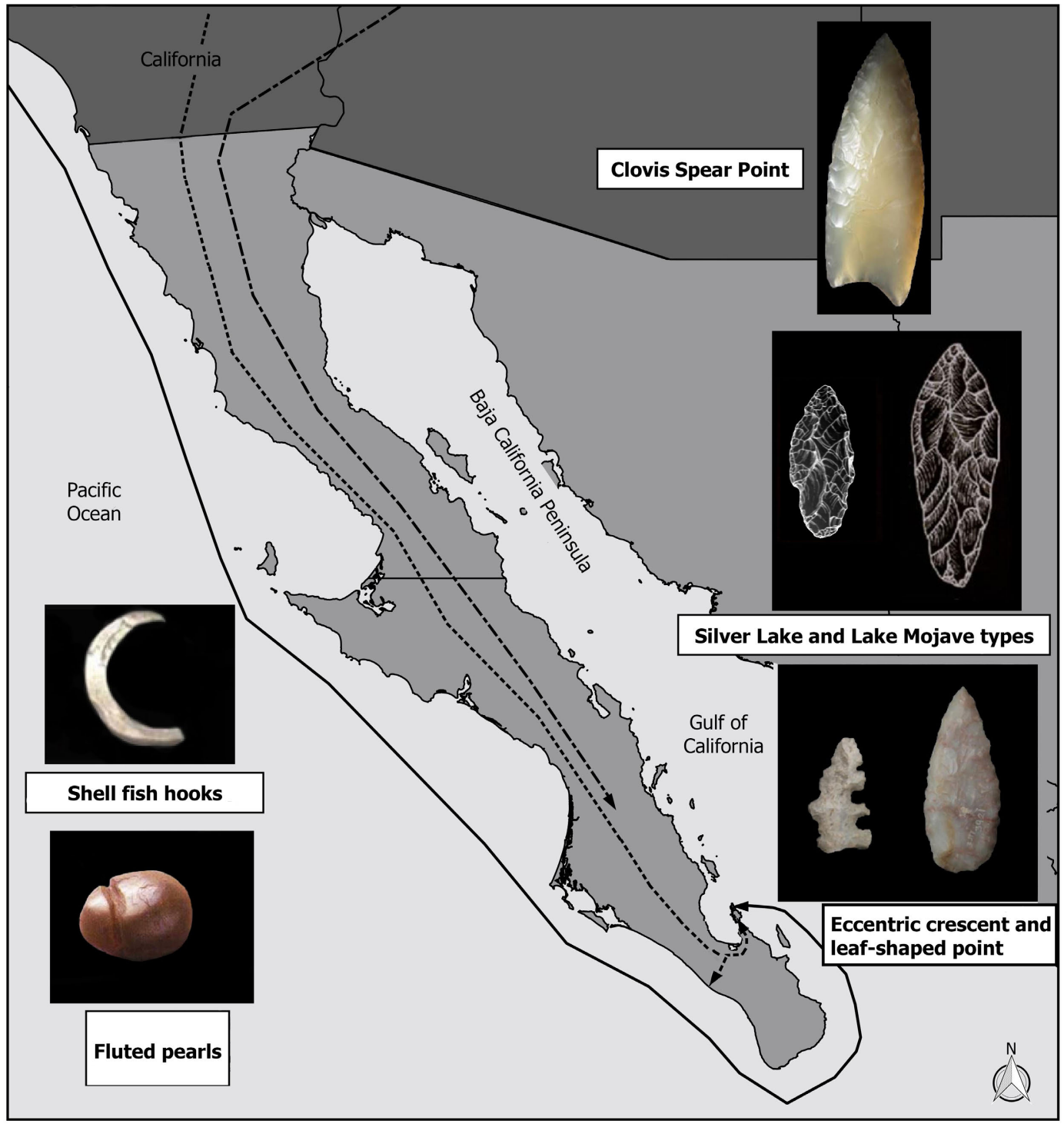

---.. WSP or WPL Tradition Route

---. Paleoindian Route

— Coastal migration Route

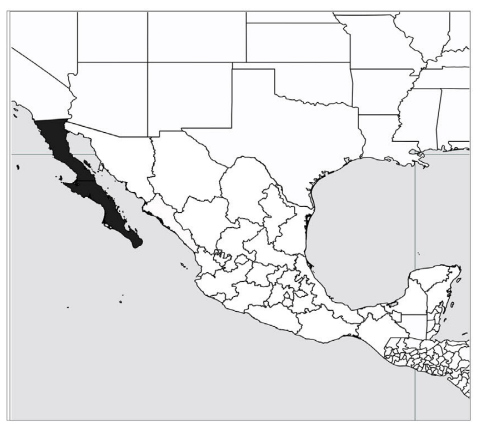

Fig. 10. Possible early migration routes on the Baja California Peninsula. 
were recovered at Covacha Babisuri (Table 1; Fujita 2010, Fujita and Melgar 2014). It is important to mention that milling and hand stones, hammer stones, and abraders were present during this early period. The most frequent projectile point type is leaf-shaped. The majority of these points could have been used as knives and one could have been a drill. A single fragmentary stemmed point was recovered from the early deposits of Covacha Babisuri. It does not have barbed shoulders, which is different from the Channel Islands stemmed points, and the presence of shoulders is different from the Western Stemmed Point pattern (Fujita and Melgar 2014). The presence of leaf-shaped points and an eccentric crescent is similar to the WPL and Paleocoastal traditions.

The shell and coral tools and containers were important components of archaeological assemblages on both islands, especially Espíritu Santo (Fig. 6d, Table 1). Fossil shells radiocarbon dated between 35,500 and more than 47,500 years old were utilized as tools and containers at the Covacha Babisuri site (Table 1; Fujita 2010, Fujita and Melgar 2014).

The presence of partially or fully fluted Pinctada mazatlanica pearls and Olivella (Callianax spp.) spire-lopped beads at Covacha Babisuri indicates their use as ornaments from a very early period (Fig. 6a, b; Table 1; Fujita 2010, 2014, Fujita et al. 2017). Additionally, marine worm shells (Vermetidae) with one extremity polished were recovered and were possibly used as straws or pipes (Fig. 6e, f; Table 1; Marlett 2014:135).

\section{Final Considerations}

Based on the early-period evidence from sites on Cedros Island, Espíritu Santo Island, and the La Paz area, the most probable migration scenario is that the initial peopling of Baja California was undertaken by groups whose subsistence was principally oriented to the exploitation of marine resources and complemented by plant gathering and hunting: Paleocoastal people. These people may have followed the Pacific coast from western Canada and the northwestern United States. After passing Cedros Island, they may have arrived at the tip of the peninsula. Some entered into the Gulf of California, while others may have continued south. Those who entered the Gulf of California would have discovered a large productive bay (because Espíritu Santo Island was connected with the peninsula until $\sim 8500$ years ago) where they found coastal areas with plentiful resources that satisfied all of their requirements (Fig. 10; Fujita 2006, 2010, Fujita and Melgar 2014). At present in Mexico, the Paleocoastal tradition is only reported from sites on the Baja California Peninsula. It is also probable that a WPL hunting tradition group arrived at the Cape Region at around the same time, adopting a coastal lifeway or entering into some kind of relationship with a Paleocoastal group that is reflected in their lifestyles and materials, which were principally adapted to coastal life.

In conclusion, the group that arrived at the Cape Region of the peninsula either by land or by sea stayed and developed its own culture, oriented to an exploitation of abundantly available marine resources and continuing from approximately 12,000 years ago until the 18 th century.

\section{ACKNOWLEDGMENTS}

The project "Poblamiento de América visto desde la isla Espíritu Santo, B.C.S. [Peopling of America seen from Espíritu Santo Island, Baja California Sur]" was financed by the Instituto Nacional de Antropología e Historia (INAH), Mexico, from 2001 to 2008. Don Laylander assisted with revising and editing. Karim Bulhusen drew Figs. 1, 2, 4, 5, and 10.

\section{Literature Cited}

Ackerman, R.E. 1992. Earliest stone industries on the North Pacific coast of North America. Arctic Anthropology 29(2):18-27.

ARNolD, B.A. 1957. Late Pleistocene and recent changes in land forms, climate and archaeology in central Baja California. University of California Publications in Geography 10:201-318.

Aschmann, H. 1952. A fluted point from central Baja California. American Antiquity 17:262-263.

Beck, C., AND G.T. Jones. 1997. The Terminal Pleistocene/Early Holocene archaeology of the Great Basin. Journal of World Prehistory 11:161-236.

Beck, C., AND G.T. Jones. 2010. Clovis and Western Stemmed: population migration and the meeting of two technologies in the Intermountain West. American Antiquity 75:81-116.

Bedwell, S.F. 1973. Fort Rock Basin prehistory and environment. University of Oregon Books, Eugene, OR.

Bowen, T. 2009. The record of native people on Gulf of California islands. Arizona State Museum Archaeological Series 201. Tucson, AZ. 
Bryan, A. 1988. The relationship of the Stemmed Point Tradition: an early technological tradition in western North America. Pages 53-74 in J.A. Willig, C.M. Aikens, and J.L. Fagan, editors, Early human occupation in far western North America: the Clovis-Archaic interface. Nevada State Museum Anthropological Papers No. 21.

Carlson, R.L. 1990. Cultural antecedents. Pages 60-69 in Wayne Suttles, editor, Northwest. Volume 7, Handbook of North American Indians. W.C. Sturtevant, general editor. Smithsonian Institution, Washington, DC.

Carlson, R.L. 1996. Early Namu. Pages 83-102 in R.L. Carlson and L. Dalla Bona, editors, Early human occupation in British Columbia. University of British Columbia Press, Vancouver, British Columbia, Canada.

Davis, E.L., C.W. Brott, and D.L. Weide. 1969. The Western Lithic Co-Tradition. San Diego Museum Papers 6.

Davis, L.G., S.C. Wills, and S.J. Macfarlan. 2012. Lithic technology, cultural transmission, and the nature of the Far Western Paleoarchaic-Paleoindian Co-Tradition. Pages 47-64 in D. Rhode, editor Meetings at the margins: prehistoric cultural interactions in the Intermountain West. University of Utah Press, Salt Lake City, UT.

Des Lauriers, M.R. 2010. Island of fogs: archaeological and ethnohistorical investigations of Isla Cedros, Baja California. University of Utah Press, Salt Lake City, UT.

Diguet, L. 1905. Anciennes sépultures indigènes de la Basse-Californie meridionale. Journal de la Société des Americanistes de Paris 2:329-333.

Dillehay, T. 1997. Monte Verde: a Late Pleistocene settlement in Chile: the archaeological context. Volume 2. Smithsonian Institution Press, Washington, DC.

Dixon, E.J. 1993. Quest for the origins of the first Americans. University of New Mexico, Albuquerque, NM.

Dixon, E.J. 1999. Bones, boats and bison: archaeology and the first colonization of western North America. University of New Mexico Press, Albuquerque, NM.

ErLandson, J.M. 1994. Early hunter-gatherers of the California coast. Plenum, New York, NY.

ErLandson, J.M. 2012. A land by the sea: an ocean view of California archaeology. Pages 21-25 in T.L. Jones and J. Perry, editors, Contemporary issues in California archaeology. Left Coast Press, Walnut Creek, CA.

Erlandson, J.M., and T.J. Braje. 2011. From Asia to America by boat? Paleogeography, paleoecology, and stemmed points of the northwest Pacific. Quaternary International 239:28-37.

Erlandson, J.M., AND M. Moss. 1996. The PleistoceneHolocene transition along the Pacific Coast of North America. Pages 277-301 in L.G. Straus, B.V. Eriksen, J.M. Erlandson, and D.R. Yesner, editors, Humans at the end of the Ice Age: the archaeology of the Pleistocene-Holocene transition. Plenum Press, New York, NY.

Erlandson, J.M., M. Moss, and M. Des Lauriers. 2008. Life on the edge: early maritime cultures of the Pacific Coast of North America. Quaternary Science Reviews 30:1-14.

Erlandson, J.M., T.C. Rick, T.J. Braje, M. Casperson, B. Culleton, B. Fulfrost, T. García, D.A. Guthrie, N. Jew, D.J. Kennett, et al. 2011. Paleoindian seafaring, maritime technologies, and coastal foraging on California's Channel Islands. Science 331: $1181-1185$.

Erlandson, J.M., T.C. Rick, T. Jones, and J.F. Porcasi. 2007. One if by land, two if by sea: who were the first Californians? Pages 53-62 in T.L. Jones and K.A. Klair, editors, California prehistory, colonization, culture, and complexity. Altamira Press, Lanham, MD.

FLADMARK, K.R. 1979. Routes: alternative migration corridors for early man in North America. American Antiquity 44:55-69.

Fledge, D.W., and T. Christensen. 1999. Modeling paleoshorelines and locating Early Holocene coastal sites in Haida Gwaii. American Antiquity 64:635-652.

Fujita, H. 2006. The Cape Region. Pages 82-98 in D. Laylander and J.D. Moore, editors, The prehistory of Baja California: advances in the archaeology of the forgotten peninsula. University Press of Florida, Gainesville, FL.

Fujita, H. 2008. Informe final del proyecto "Poblamiento de América visto desde la isla Espíritu Santo, B.C.S." Technical Archives of INAH, Mexico City.

Fujita, H. 2010. Prehistoric occupation on Espíritu Santo Island, Baja California Sur, Mexico: update and synthesis. Journal of Great Basin and California Anthropology 30:17-33.

Fujita, H. 2014. Early Holocene pearl oyster circular fishhooks and ornaments on Covacha Babisuri, Espíritu Santo Island, Baja California Sur. Monographs of the Western North American Naturalist 7:129-134.

Fujita, H., And K. Bulhusen Muñoz. 2014a. Landscape, raw material, and settlement patterns in the area of La Paz, Baja California Sur. Proceedings of the Society for California Archaeology 28:117-134.

Fujita, H., and K. Bulhusen Muñoz. 2014b. Cueva Tecolote \#2: un sitio de ocupación desde el Holoceno Temprano al noreste de La Paz, B.C.S. Memorias: Balances y Perspectivas de la Antropología e Historia de Baja California 15:49-60.

Fujita, H., And M.L. Hernández Velázquez. 2017. Informe de la quinta temporada de campo del proyecto "Registro y excavación de los sitios Arqueológicos del Municipio de La Paz, B.C.S.: Recorrido de superficie del Area de Tecolote, Balandra y Conquista Agraria (Faro Punta Marquez)." Technical Archives of INAH, Mexico City.

Fujita, H., and A. Hernández del VilLaR. 2016. Informe de la cuarta temporada de campo del proyecto "Registro y excavación de los sitios Arqueológicos del Municipio de La Paz, B.C.S.: sitios A-56 Cerro de la Calavera y A-119 Cañada de la Enfermería \#3 (pozo 2) en 2015." Technical Archives of INAH, Mexico City.

Fujita, H., C. Cáceres, And A.F. Ainis. 2017. Pearl ornaments from Covacha Babisuri site on Espíritu Santo Island, Baja California Sur, Mexico. Pacific Coast Archaeological Society Quarterly 53(2\&3):63-86.

Fujita, H., C. García, D. Larios, and K. Bulhusen. 2013. Informe de la primera temporada del proyecto "Registro y Excavación de los sitios arqueológicos del Municipio de La Paz, B.C.S.: excavación en el sitio A-56 Cerro de la Calavera \#1." Technical Archives of INAH, Mexico City.

Fujita, H., AND E. MELgar. 2014. Early Holocene use of Pleistocene fossil shells for hide-working at Covacha 
Babisuri on Espíritu Santo Island, Baja California Sur, Mexico. Journal of Island and Coastal Archaeology 9:111-129.

Fujita, H., And A. Porcayo Michelini. 2014. Poblamiento de la península de Baja California. Pages 95-122 in Eduardo Corona Martínez and Joaquín Arroyo Cabrales, coordinators, Perspectivas de los estudios en México: un homenaje a la trayectoria del ingeniero Joaquín García-Bárcena. Colección Arqueología, INAH, Mexico City.

Fujita, H., and G. Poyatos. 2007. Prehistoric quarrying and tool manufacturing at El Pulguero, Baja California Sur. Pacific Coast Archaeological Society Quarterly 39(2\&3):23-36.

García Hernández, C., D.L. Córdova, and H. Fujita. 2015. Informe de la segunda temporada de campo del proyecto "Registro y Excavación de los sitios arqueológicos del Municipio de La Paz, B.C.S.: excavación en el sitio A56 Cerro de la Calavera \#1." Technical Archives of INAH, Mexico City.

González-José, R., A. González-Martín, M. HernánDEZ, H.M. Pucciarelli, M. SARdi, A. Rosales, and S. van Der Molen. 2003. Craniometric evidence for Paleoamerican survival in Baja California. Nature 425:62-65.

Gruhn, R., and A. Bryan. 2008. An interim report on two rock shelter sites with Early Holocene occupation in the Northern Baja California Peninsula. Pacific Coast Archaeological Society Quarterly 42(2\&3):1-16.

Guía, A. 2008. "Los Peces en el tiempo: Informe arqueozoológico de los materiales faunísticos del proyecto "El Poblamiento de América visto desde la isla Espíritu Santo, B.C.S.: temporada 2006 en varios sitios de la isla Espíritu Santo." Centro INAH BC., Ensenada.

GUíA, A. 2011. Informe arqueozoológico de los materiales faunísticos del proyecto "El Poblamiento de América visto desde la isla Espíritu Santo, B.C.S.: temporada 2006 en la Covacha Babisuri." Centro INAH BC., Ensenada.

GutiérRez, M.L., And J.R. Hyland. 2002. Arqueología de la Sierra de San Francisco. Colección Científica No. 433, INAH, Mexico.

Hyland, J.R., and M.L. GutiérRez. 1995. An obsidian fluted point from central Baja California. Journal of California and Great Basin Anthropology 17: 126-128.

Jenkins, D.L., L.G. Davis, T.W. Stafford Jr., P.F. Campos, B. Hockett, G.T. Jones, L.S. Cummings, C. Yost, T.J. Connolly, R.M. Yohe II, ET AL. 2012. Clovis age Western Stemmed projectile points and human coprolites at the Paisley Caves. Science 337:223-228.

Jones, T.L., And D.J. KennetT. 2012. A land impacted? The Younger Dryas Boundary event in California. Page 37-38 in T.L. Jones and J. Perry, editors, Contemporary issues in California archaeology. Left Coast Press, Walnut Creek, CA.

KowTA, M. 1984. The "layer cake" model of Baja California prehistory revised: an hypothesis. Pacific Coast Archaeological Society Quarterly 20(1):1-16.

Laylander, D., AND J.D. MoORe, EDITORS. 2006. The prehistory of Baja California: advances in the archae- ology of the forgotten peninsula. University Press of Florida, Gainesville, FL.

Marlett, C. 2014. Shells on a desert shore. University of Arizona Press, Tucson, AZ.

Massey, W. 1955. Culture history in the Cape Region of Baja California. Doctoral dissertation, University of California, Berkeley, CA.

Massey, W. 1966. Archaeology and ethnohistory of Lower California. Pages 38-58 in G.F. Ekholm and G.R. Willey, editors, Archaeological frontiers and external connections. Volume 4, Handbook of Middle American Indians. University of Texas Press, Austin, TX.

Meltzer, D.J., D.K. Grayson, G. Ardila, A.W. Barker, D.F. Dincauze, C.V. Haynes, F. Mena, L. Nuñez, and D.J. Stanford. 1997. On the Pleistocene antiquity of Monte Verde, southern Chile. American Antiquity 62:659-663.

Moratto, M.J. 1984. California archaeology. Academic Press, San Diego, CA.

Porcayo Michelini, A. 2005. Primeros resultados de las excavaciones del sitio Ignacio Zaragoza. Memorias: Balances y Perspectivas de la Antropología e Historia de Baja California 6:23-31.

Porcayo Michelini, A. 2009. Proposal for identifying San Dieguito sites in Baja California. Proceedings of the Society for California Archaeology 22.

RaAb, M., J. Cassidy, A. Yatsko, and W.J. Howard. 2009. California maritime archaeology: a San Clemente Island perspective. AltaMira Press, Lanham, MD.

Rick, T., J. ErLandson, N.P. Jew, and L.A. Reeder-Myers. 2013. Archaeological survey, paleogeography, and the search for Late Pleistocene paleocoastal peoples of Santa Rosa Island, California. Journal of Field Archaeology 38:324-331.

Rick, T., J. Erlandson, and R. Vellanoweth. 2001. Paleocoastal marine fishing on the Pacific Coast of the Americas: perspectives from Daisy Cave, California. American Antiquity 66:595-613.

Ritter, E.W. 2006. South-central Baja California. Pages 99-116 in D. Laylander and J.D. Moore, editors, The prehistory of Baja California: advances in the archaeology of the forgotten peninsula. University Press of Florida, Gainesville, FL.

RIvet, P. 1909. Recherches anthropologiques sur la BasseCalifornie. Journal de la Société des Américanistes de Paris 6:147-253.

Rogers, M.J. 1945. An outline of Yuman prehistory. Southwestern Journal of Anthropology 1:167-198.

Rogers, M.J. 1966. Ancient hunters of the far west. Union-Tribune Publishing, San Diego, CA.

TEN KATE, H. 1883. Quelques observations ethnographiques recueillies dans la presqu'île californienne et en Sonora. Revue d'Ethnographie 2:321-362.

Walters, M.R., AND T.W. StaFFord JR. 2007. Redefining the age of Clovis: implications for the peopling of the Americas. Science 315:1122-1126.

Received 27 February 2017 Revised 18 January 2018

Accepted 26 January 2018

Published online 18 September 2018 